University of New Hampshire

University of New Hampshire Scholars' Repository

$12-2011$

\title{
A comparison of presettlement and modern forest composition along an elevation gradient in central New Hampshire
}

\author{
Steven P. Hamburg \\ Brown University \\ Charles V. Cogbill \\ Wendy Y. Sugimura
}

Matthew A. Vadeboncoeur

Brown University, matt.vad@unh.edu

Follow this and additional works at: https://scholars.unh.edu/ersc

Part of the Ecology and Evolutionary Biology Commons, and the Forest Sciences Commons

\section{Recommended Citation}

Vadeboncoeur MA, Hamburg SP, Cogbill CV, Sugimura WY. 2012. A comparison of presettlement and modern forest composition along an elevation gradient in central New Hampshire. Canadian Journal of Forest Research 42:190-202

This Article is brought to you for free and open access by the Institute for the Study of Earth, Oceans, and Space (EOS) at University of New Hampshire Scholars' Repository. It has been accepted for inclusion in Earth Systems Research Center by an authorized administrator of University of New Hampshire Scholars' Repository. For more information, please contact Scholarly.Communication@unh.edu. 


\title{
A Comparison of Presettlement and Modern Forest Composition along an Elevation Gradient in central New Hampshire
}

\author{
Matthew A. Vadeboncoeur \\ University of New Hampshire \\ Steven P. Hamburg \\ Environmental Defense Fund \\ Charles V. Cogbill \\ Plainfield, VT \\ Wendy Y. Sugimura \\ Brown University
}

\begin{abstract}
Tree species composition is influenced not only by edaphic and climatic factors, but also by natural and humancaused disturbances. To understand interactions among these influences, we compared forest species composition data from the time of European settlement with modern data. We derived elevation data for 2,529 trees mapped by early land surveys (1770-1850) across a 1,000-m elevation gradient in central New Hampshire, and compared these with modern data (2004-9) from the Forest Inventory and Analysis program (123 plots containing 2126 trees), and from permanent plots representing case studies of different land-use histories. Spruce and beech are much less abundant today at all elevations than they were prior to settlement, while maples and birches have increased. Fir, hemlock, pines, and oaks have changed little in distribution, though pines and oaks increased in abundance somewhat. Land-use history (agriculture below $500 \mathrm{~m}$ and cutting of various intensities at all elevations) is likely the primary explanation for these shifts, though climate change is also an important factor for some. A clearer understanding of presettlement forest composition improves our ability to separate the relative importance of natural and human-driven influences on the species composition of today's forests.
\end{abstract}

This reformatted accepted manuscript is made available by the authors, in accordance with the author rights policy of NRC Research Press.

The formatted final version is available from the publisher at http://dx.doi.org/10.1139/10.1139/x11-169

This document should be cited as:

Vadeboncoeur, M.A., S.P. Hamburg, C. V Cogbill, and W.Y. Sugimura. 2012. A comparison of presettlement and modern forest composition along an elevation gradient in central New Hampshire. Canadian Journal of Forest Research 42(1): 190-202. 


\section{Introduction}

The forests of northern New England have changed dramatically since they were first seen by European settlers in the late $18^{\text {th }}$ Century; understanding these changes requires an unbiased landscape-scale historical data source. Few if any forest stands remain that have not been directly affected by human activities, and those that do exist are probably not representative of the dominant forests of several hundred years ago. Even if remnant uncut forest patches were once representative, changes in climate (Hamburg and Cogbill 1988), precipitation chemistry, and $\mathrm{N}$ deposition (Driscoll et al. 2003) have impacted even the most remote stands. Historic land-use practices, of which commercial timber harvesting and small-scale agriculture are the most widespread in New England, can dramatically alter regeneration dynamics (Rhoads 2005; Bellemare et al. 2002). To understand the effect of past land-use activities in combination with exposure to chronic air pollution, the introduction of exotic pests, and increasing rates of climate change on New England's forested ecosystems, it is necessary to accurately describe the composition of the forest prior to colonial settlement. In mountainous regions where elevation is a strong determinant of species composition, comparisons with modern data sets must account for elevation.

Witness trees (trees cited as markers or references for land survey lines on the ground) provide a robust and unbiased dataset with which to characterize the presettlement forest of New England (e.g. Foster 1992; Cogbill et al. 2002). In the European settlement of northern New England, witness trees were blazed by surveyors at the corners of each lot (Siccama 1971; Lorimer 1977). The species of each witness tree was often recorded in written accounts or on maps. Based on detailed investigations of the history of central New Hampshire (e.g. Hamburg 1984), we do not believe fraud and settlement influence prior to survey are major problems in our study area. However, some European settlement may have pre-dated formal division of the land, particularly along the Connecticut River. While surveyors were not botanists and may have misidentified some trees, the region's trees are easily identified to genus, and most genera are represented by only one or two canopy species, limiting the potential for identification errors. The large number of surveyors working in the region over several decades further mitigates the potential for systematic error. Several researchers have demonstrated that surveyors showed little bias in the selection of the size or species of witness trees (Siccama 1971; Maines and Mladenoff 2000).

Forest reconstruction from witness trees provides a more detailed and extensive understanding of forest composition in the "presettlement" period than can be created from the pollen record or early surveys by foresters, which in New England occurred after the peak of agricultural clearing and after the start of industrial logging. In this paper, we use the term "presettlement" to refer to the state of the forests as surveyed in the late $18^{\text {th }}$ and early $19^{\text {th }}$ centuries, before widespread clearing of the region's forests, though we recognize that native people lived in the region and may have influenced parts of the landscape before this time. Such reconstructions allow us to observe forest change over the life span of the longer-lived trees (Clawson 1979; Cogbill et al. 2002), during a period of extensive and intensive land-use changes. Viewing changes in species composition and spatial distribution over centuries allows us to better assess successional trends that are key to the development of sustainable management practices and to predicting how they might change in the future in response to additional anthropogenic stresses (e.g. climate change, exotic pests).

We compared witness tree composition with a variety of more recent data sets to determine whether and how the elevation gradient in species composition of central New Hampshire forests has changed since the late $18^{\text {th }}$ century, specifically testing three hypotheses:

1. Early-successional species are more abundant today than prior to settlement, due to extensive clearing in the $19^{\text {th }}$ century, as well as historical timber harvesting and modern forest management across the landscape.

2. With climatic warming, species with southern and low-elevation distributions have increased at the expense of species with northern and high-elevation distributions.

3. The ecotone between northern hardwood and montane conifer forest types has moved upward in elevation, due to climatic warming and historical forest harvest practices that favored the regeneration of hardwood species.

To test these hypotheses, we compared the presettlement elevation distribution of each genus 
to its current elevation distribution in USFS Forest Inventory and Analysis (FIA) data. We also compared presettlement composition with forest inventory data from long-term study plots with a variety of representative land-use histories in a narrow elevation band. While many of the presettlement data we used have been included in regional analyses before (e.g. Cogbill et al. 2002), this is the first study of witness tree species composition in New Hampshire to examine trends with elevation. Future studies of changes occurring in forest ecosystems due to human influence will benefit from an improved understanding of early historical composition across the gradients of elevation and aspect in this mountainous region.

\section{Methods \\ Study Area}

We compiled witness tree data from the White Mountain and upper Connecticut River valley regions of New Hampshire, (Fig. 1a) including 26 towns in Grafton, Coos, and Carroll counties, covering about $2600 \mathrm{~km}^{2}$ in central New Hampshire. Elevation ranges from $100 \mathrm{~m}$ on the Connecticut River to 1,917 $\mathrm{m}$ at Mt. Washington (Fig. 1b). Treeline typically occurs between 1200 and $1300 \mathrm{~m}$, but climatically is expected to occur around $1500 \mathrm{~m}$. The area receives approximately $130 \mathrm{~cm}$ of precipitation annually, with greater amounts at higher elevations (Bailey et al. 2003). Annual mean temperatures range from $9 \circ \mathrm{C}$ at Plymouth to $-3 \circ \mathrm{C}$ at Mt. Washington, with a surface air-temperature lapse rate of -5 to -6 - $C$ per 1000 m elevation. (Richardson et al. 2004).

In this region, native people likely had limited influence on forest composition outside the river floodplains (Russell 1980; Hamburg 1984), and there is no evidence of extensive fires in this region prior to European settlement (Day 1953). The mountain forests that are our primary study focus were therefore largely unaffected by human activity at the time the surveyors were recording witness trees, though the lowest elevation forests (below $250 \mathrm{~m}$ ) should be interpreted with some caution. In the late 1700 s and early 1800 s, the more accessible land was surveyed into lots and cleared to support small-scale agriculture, which peaked around 1860, at which time $30 \%$ of Grafton County was cleared (Fig. 2a). In the late 1800 s much of the agricultural land was abandoned. Between 1880 and 1925 large-scale commercial logging was the mainstay of the regional economy and essentially all land not previously cleared for agricultural purposes was cutover. The intensity of cutting varied widely across the landscape, depending on accessibility and timber quality. Today, the area is $88 \%$ forested, with most non-forest area below 300 m (Fig. 2a).

\section{Witness tree data sources and handling}

We collected archival data (Table 1) from six repositories: the New Hampshire State Library, the New Hampshire Division of Records Management and Archives, the New Hampshire State Historical Society, the Grafton County Deeds Office, the Dartmouth College Library, and the Town Office of Campton, NH. Data were extracted from early town records, including proprietor's books and maps, which detail land surveys with witness trees along town boundaries and at the corners of individual lots. No maps dated later than 1850 were used unless they were derived from earlier (usually undated) surveys. Most of the later maps are from grants in the more remote mountainous parts of the study region, which were never settled.

Tabular and narrative data were plotted on a map of the original lots established in each town. These locations were then superimposed on a 7.5 minute USGS topographic map with a zoom-transfer scope, and the elevation of each tree recorded. Maps acquired more recently were scanned and entered into a GIS database using ArcGIS 9.1, allowing us to automate the extraction of elevation, aspect (8 standard categories: N, NE, E, etc.), and slope for each witness tree from a USGS digital elevation model (seamless.usgs.gov). Witness tree data for Campton were previously tabulated in 100-m elevation classes by Hamburg (1984), and data for Lebanon were adapted from a map by Torbert (1935). Because trees on early surveyor's maps were usually only identified to genus, our analyses group trees by genus (Table 2).

\section{Witness tree mapping sensitivity analysis}

To assess the potential effect of the spatial inaccuracy of the proprietors' maps on the elevation and aspect assigned to each tree, we compared elevation and aspect data derived from a linearly georeferenced proprietor's map of Campton with corresponding data from a version we corrected using the town's current GIS tax map. Root-meansquared elevation error between the maps was 33 $\mathrm{m}$. Corrected lot-corner elevations were in the same $100-m$ elevation class $79 \%$ of the time and were one class away $20 \%$ of the time, with no bias towards 
higher or lower elevations. Only $40 \%$ of lot corners remained in the same aspect category when corrected, though $74 \%$ were within one aspect category and $84 \%$ were within two.

\section{Comparison between presettlement and modern forests at the landscape scale}

The FIA periodically inventories forest plots distributed systematically across each county. There are 123 FIA plots with coordinates and elevations in the 26-town study area that were surveyed between 2004 and 2009, containing a total of 2,126 trees of at least $20 \mathrm{~cm}$ diameter (Fig. 2b). Phase II tree- and plot-specific data for New Hampshire were downloaded from www.fia.fs.fed.us on 1/6/2011. For privacy reasons, FIA does not report highly reliable location data, but at the scale of this analysis, the effect should be negligible since plot elevations remain accurate, and even incorrect coordinates remain within the correct county. For plots in each 100-meter elevation class, we calculated the mean percentage of trees $\geq 20 \mathrm{~cm}$ diameter at breast height in each genus, as this is the class of trees that surveyors would primarily have recorded (Hamburg and Cogbill 1988). For each genus in each elevation category, we tested the hypothesis that its abundance differed between the presettlement and FIA datasets with the poisson.test function in R 2.10.1 (r-project.org).

\section{Comparison to historic and modern forest case studies}

We also compared our reconstruction of presettlement forest composition with that found by early historic surveys at Waterville and Low and Burbank's Grant (Chittenden 1904), and surveys of two unlogged modern primary (Martin 1977; Martin and Bailey 1999; Carbonneau 1986) and post-harvest secondary forests (Leak and Smith 1996; Hamburg 1984; Rhoads 2005; Bormann et al. 1970). Plot locations (where known) are shown in Fig. 1 a. Where possible, datasets were trimmed to include only trees between 580 and $700 \mathrm{~m}$ in elevation (the elevation range of the Chittenden surveys), though the post-agricultural case-study sites are somewhat lower in elevation (400-620 m; Hamburg 1984; Rhoads 2005), as is Mountain Pond (520-550 m; Carbonneau 1986). In each case we report the fraction of trees $\geq 20 \mathrm{~cm}$ in each genus, as described above. While these data are from specific locations and are less spatially extensive than the presettlement or FIA datasets, they are intended to serve as case studies illustrating representative forest composition across different histories, rather than as direct comparisons to the presettlement data.

Similarity between forest communities was assessed using Sørensen's similarity coefficient (MeullerDombois and Ellenberg 1974), which we calculated for each pairwise comparison within these data sets. This metric is calculated as the sum across all species of the minimum abundance of a given species across the two sites. It can vary between 0 and 1 , with greater values indicating higher degrees of similarity between communities.

\section{Effect of Aspect on forest composition}

Because the effect of elevation on species composition may be altered by aspect in mountainous regions, we analyzed aspect data for the subset of trees entered into the GIS system ( $n=$ 1342). Trees on slopes of $<5$ o were not assigned an aspect. For the seven most abundant genera (Table 2 ), we generated logistic models ( 1 = genus present, $0=$ other genus present) using linear and quadratic terms for elevation, and aspect as a categorical variable. Logistic models were generated using the glm function in R.

\section{Results}

\section{Pre-settlement forest composition by elevation class}

All genera examined showed major changes in abundance with elevation in both the presettlement and modern FIA datasets (Fig. 3). Below 400 m, the presettlement forest was dominated by beech and hemlock, with spruce, maple, birch, and pine also common. Oak, ash, and pine were moderately abundant, especially at the lowest elevations. In the lowest elevation class $(<200 \mathrm{~m})$, no single genus was dominant, and richness and diversity were greater than at any other elevation (Fig. 4). At middle elevations, (400-700 m) spruce, beech, and birch were dominant, with lesser amounts of maple, hemlock, and fir. Above $700 \mathrm{~m}$, spruce, fir, and birch were all abundant, with fir replacing spruce at the highest elevations.

\section{Comparison between presettlement and modern forests at the landscape scale}

Spruce and beech were significantly less abundant in the modern FIA dataset in most elevation classes (Fig. 3a,d). Fir had a similar distribution in the two datasets, being slightly more abundant in the FIA 
data (Fig. 3b). Birch was apparently much more abundant in the FIA dataset than in the presettlement data, but the difference was only significant from 200-500 $\mathrm{m}$ and 800-900 m (Fig. 3c). Maple was significantly more abundant in the FIA dataset than the presettlement dataset between 200 and $800 \mathrm{~m}$ (Fig. 3e).

Among species that decreased monotonically with elevation in the presettlement data, distributions were generally similar in the two datasets. Pine, oak, and ash appear to have generally increased at low elevations, while hemlock may have decreased, especially below $200 \mathrm{~m}$, where it was absent in the FIA dataset (Fig. 3f). Note that statistical power to detect differences varies greatly among the elevation classes due to overall sample sizes (Fig. 2b).

Basswood and elm were moderately abundant at low elevations in the presettlement dataset (data not shown; sample sizes too small to test significance). Basswood accounted for $8 \%$ of witness trees between 100 and 200 m elevation and $<1 \%$ for the 200-300 and 300-400 m elevation classes. Elm accounted for $4 \%$ from $100-200 \mathrm{~m}$, and about $1 \%$ in all other classes up to $700 \mathrm{~m}$. In the modern FIA data, basswood accounted for 2\% in the 100-200 m class and $<1 \%$ from $200-400 \mathrm{~m}$, while elm was only present in the $100-200 \mathrm{~m}$ class at $1 \%$.

\section{Comparison to historic and modern primary forest case studies}

Forest composition in our witness tree data between 580 and 700 m elevation (Fig. 5a) was very similar to the early forest survey data in the same elevation range roughly a century later (Fig. $5 \mathrm{~b}-\mathrm{c}$ ), with similarity coefficients of 0.85 and 0.87 , respectively (Table 3). Modern stands without a history of cutting, which are often regarded as a good proxy for the presettlement forest, however had surprisingly different composition. One such stand, The Bowl, is dominated by beech, maple, and yellow birch, with much less spruce than the presettlement forest (Fig. 5d). This area was less similar to the presettlement forest than were the 1903 surveys, with community similarity coefficient of 0.59-0.62. At Mountain Pond (Fig. 5e), beech and maple accounted for $>80 \%$ of stems $>20 \mathrm{~cm}$, with a similarity coefficient of only 0.41 . In each of these modern unlogged forests, spruce is now far less common than it was regionally prior to settlement or in the early $20^{\text {th }}$ century surveys.

\section{Comparison to modern secondary forest case studies}

We compared presettlement forest composition with modern data from long-term study plots in secondary forests with disturbance histories representative of the landscape (Fig. 5, Table 3). Watershed 6 at the Hubbard Brook Experimental Forest (HBEF) was partially cutover circa 1880 and 1910, with some salvage logging following the 1938 hurricane. Between 580 and $700 \mathrm{~m}$, this forest is now dominated by sugar maple, and has the lowest richness in the $20+\mathrm{cm}$ dbh size class of any of the sites we compare here. This site's similarity coefficient with our presettlement reconstruction at the same elevation was 0.46-0.56. However, forests at Bartlett Experimental Forest (BEF), also unmanaged since being cut circa $1880-1900$, are as similar to the presettlement forests (similarity of $0.77-0.79$ ) as the primary forests examined. BEF stands that were managed during the $20^{\text {th }}$ century are much less similar to the presettlement forest (similarity of $0.48-0.49$ ).

Forests $<100$ years of age growing on abandoned agricultural lands (sampling locations shown in Fig 1a) are the least similar in forest composition to the presettlement forest with similarity coefficients of 0.22-0.27. Even these numbers may overstate similarity, as maple in the presettlement forest was probably mostly sugar maple, as in modern primary forests, while red maple is dominant in the old-field forests. Forests growing on abandoned unplowed pastures are more similar to the presettlement forest (similarity $=0.57$ ) than forests regrowing on plowed fields due to the abundance of spruce, though they also have a preponderance of red maple over sugar maple. Abandoned woodlots (similarity = 0.54 ) show high abundances of sugar maple and hemlock, and low abundance of spruce.

\section{Effect of Aspect on forest composition}

The witness tree data yielded little indication that aspect affected forest composition. Of the seven genera examined, only the logistic model for pine had significant ( $\alpha=0.05$ ) aspect effects. South, southeast, and southwest aspects showed significantly greater pine abundance than average.

\section{Discussion}

\section{Landscape patterns in the presettlement forest}

The presettlement forest composition presented in this paper is generally consistent with other 
reconstructions in New England based on witness trees (Cogbill et al. 2002; Siccama 1971; Lorimer 1977; Satterson 1977; Foster 1992) and lake sediment pollen (e.g. Shuman et al. 2004). Elevation had a strong effect on species: the most abundant presettlement genus shifts from pine $(<200 \mathrm{~m})$ to beech $(200-500 \mathrm{~m})$ to spruce $(500-1000 \mathrm{~m})$ to fir (>1000 m). We found few significant effects of aspect independent of elevation, perhaps due to the limited data set we were able to utilize, and perhaps due to noise introduced to the data by surveying error. The preference of pine for south-facing sites at low elevations is expected, as eastern white pine is a southern, xeric species relative to our study area.

\section{Changes in early vs. late- successional species}

We hypotheisezed that early successional species would increase in abundance at the expense of late successional species, due to more frequent and more intense disturbance (especially cutting and clearing) over the past two centuries, relative to the period preceding the witness tree surveys. Beech and spruce, which both declined dramatically, are shade-tolerant later-successional species which fare poorly early in succession (though beech rootsprouts sometimes dominate young forests after harvest or disturbance). Above $800 \mathrm{~m}$, early successional white birch appears to have replaced most of the lost spruce and beech, while below this elevation gains were made by species with a range of life history strategies: late-successional sugar maple, early-mid successional yellow birch and red maple, and early-successional white birch. Hemlock, a classic late-successional species, apparently declined dramatically in the lowest elevation class (but see below for data considerations specific to this elevation range), while roughly maintaining its presettlement distribution above $200 \mathrm{~m}$. Pine, which often dominates early succession elsewhere in New England, has apparently increased at the lowest elevations, along with minor early-successional genera including aspen (Populus spp.) and cherry (Prunus spp.) (data not shown).

\section{Changes in northern vs. southern species and ecotone movement}

Central New Hampshire is a region where multiple forest types occur in close proximity; across the elevation gradient we examined, species representing the transition hardwoods, the northern hardwoods, and montane conifer forest types are all present (Westveld 1953; Cogbill et al. 2002). Because the region has warmed by about $1.7^{\circ} \mathrm{C}$ since the mid- 1800s, (Hamburg and Cogbill 1988), we hypothesized that trees with southern distributions increased at the expense of those with northern distributions, and that the mean elevation at which each genus is found would increase. While climate-driven range shifts are more complex than such simple hypotheses suggest (Davis et al. 1998) and may occur slowly even in a rapidly changing climate (Davis 1989), some studies (Hamburg and Cogbill 1988; Beckage et al. 2008) imply that such changes may have already occurred in the region.

In the data we examined, there was not a universal decline in high-elevation species. While major declines were seen in spruce at all elevations, no systematic pattern was evident for fir (Fig. 3). Across much of the elevation gradient, large declines in the abundance of beech, which is at the middle of its range in the study area, were matched not by increases in southern species, but in maples and birches, which are also in the middle of their ranges. Both pine and oak appear to have made gains at the lowest elevations, though the low elevations are perhaps most susceptible to pre-survey human impacts, and have the least forest cover today, resulting in a small modern sample (Fig. 3).

Putting spruce and fir together as an indicator of the montane conifer vegetation type, a trend becomes apparent that this vegetation type is less abundant at all elevations today than prior to settlement (Fig. 6 ). The elevation where spruce and fir make up at least $50 \%$ of the forest has shifted from about 700 to about $900 \mathrm{~m}$, although sample size and statistical power are low at these elevations (Fig. 2b). This may be due in part to heavy cutting of spruce, but the similar lack of spruce in mid-elevation unlogged stands (Fig. 5d-e) lends support to the hypothesis that there are also climate-driven shifts in the ecotone. Beckage et al. (2008) documented an upward ecotone movement on the order of 50-100 $m$ in just the last four decades using aerial photographs and forest inventory data from Vermont, and others have found similar shifts elsewhere in the world (e.g. Lenoir et al. 2008; Kelly and Goulden 2008).

\section{The role of land use in changing forest composition}

Despite our hypotheses, changes in abundance and elevation distribution don't separate neatly along the lines of early- vs. late-successional or warm vs. cold-climate species. To some extent, this is because the presettlement data are often not resolved to species, so our analysis lumped congeneric species 
together despite sometimes rather different lifehistory traits (e.g. white and yellow birch, red and sugar maple). The long-term impacts of various human land-uses also complicate the picture, so here we summarize likely causes of changes in each genus individually.

\section{Decline of spruce}

Spruce is an important component of forest regeneration on abandoned pasture lands and plowed fields (Fig. 5j-k), due to selective grazing by cattle and sheep, though eventually hardwoods replace the even-aged spruce below $500 \mathrm{~m}$ (Rhoads 2005). On the other hand, the near-absence of spruce from forests cutover in the last two centuries is due in part the thoroughness with which it was harvested, especially in the late 1800s (Sargent 1884). In some areas of the White Mountains today, sharp spruce-stand boundaries are directly traceable to the areas cut or burned in this period (Cogbill and White 1991). Harvesting does not fully explain the loss of spruce, which is also far less abundant in modern unharvested forests (Fig. $5 \mathrm{~d}$-e) than it was presettlement (Fig. 5a) or in uncut forests circa 1900 (Fig. 5b-c).

Climate may be an additional factor in long-term spruce decline. Assuming spruce is limited at low elevations by summer temperature, the 1.7으 warming from 1835 to 1983 would correspond to a $400 \mathrm{~m}$ upward shift in the climatic envelope for spruce (Hamburg and Cogbill 1988). Shifting the presettlement abundance of spruce upslope by 400 $\mathrm{m}$ would put it at $10 \%$ abundance at $700 \mathrm{~m}$ and shift its peak abundance to between 1200 and 1300 m, where treeline is maintained by thin soils, high winds, and ice accumulation (Cogbill and White 1991; Richardson et al. 2004). Rather than a simple shift in elevation, Fig. 3a shows that spruce has declined at all elevations. Westveld (1953) observed that spruce did not return after being selectively removed from mixed stands; it is a poor competitor under today's warmer climate (Eager and Adams 1992), and has simultaneously become less coldtolerant due to acid deposition (Johnson 1992; Hawley et al. 2006). Given its high sensitivity to climate change over its post-glacial history (Shuman et al. 2004), red spruce will be largely eliminated from New Hampshire over the next century (Iverson and Prasad 2002).

Decline of beech
In contrast to cutover forest land, with advance regeneration of beech and the potential for cut beeches to root-sprout, abandoned agricultural lands typically have little beech even after 100 years (Fig. 5j-k), due to poor seed dispersal and a lack of defense against grazing (Rhoads 2005). The strong agricultural land-use history of the lower elevation parts of the study area (Fig. 2a) likely explains much of the dramatic decline in beech. Another potential contributor to the decline of large canopy beech is beech bark disease (Houston 1994), which eventually kills many of the mature beech it infects. Stands heavily affected by beech bark disease often have high rates of beech regeneration, but declining beech in the $20+\mathrm{cm}$ diameter category that we examined here. Siccama (1971) shows a similarly dramatic decline in beech in northern Vermont since settlement.

\section{Increases in maple}

The genus that has undergone the most dramatic increase in importance at the middle elevations is maple (witness tree data indicate primarily sugar maple where specified, Cogbill et al. 2002). Siccama (1971) observed a similarly dramatic increase in maple since presettlement in Vermont below $760 \mathrm{~m}$ elevation. In modern forests (Fig. 5), sugar maple appears to have filled in after the dramatic decline in spruce. On farms, sugar maples were often left in woodlots to provide maple sugar, and along with sugar maples planted along roadsides, provided an important seed source in adjacent cleared lands after abandonment. However, land-use history cannot explain the dramatic apparent increases in sugar maple in areas with no agricultural history (e.g. Fig. $5 \mathrm{~d}$-e, g-i), or at elevations above $600 \mathrm{~m}$ which were never farmed (Fig. 3e, Fig. 5f).

The dramatic expansion of sugar maple into habitats it did not occupy previously is an important consideration in assessing the potential causes of apparent region-wide sugar maple decline. Red maple, a fast-growing, disturbance-tolerant generalist species, also contributes to the increased abundance of maple in modern secondary forests in the study area (Fig. 3), and throughout the region (Abrams 1998).

Increases in birch

Siccama (1971) found major increases in birch since settlement in northern Vermont, and our findings are similar (Fig. 3d). Most of this increase is white birch, an early successional species, which has 
certainly increased as forest management continually re-initiates secondary succession in patches across the landscape. White birch often dominates succession after severe fires that expose mineral soil, such as occurred throughout the region circa 1900 following timber removal (Goodale 1997). In the modern FIA data set, white birch is generally more abundant than yellow birch at all elevations, especially above 700 meters, where it apparently increased dramatically (Fig. 3) as spruce declined.

\section{Caveats regarding data from low elevations}

We compared two data sets (witness trees and FIA inventories) that are similar in overall sample number, but which differ in the elevation distribution of sampling. Low-elevation floodplains are oversampled in the witness tree data (Fig. 2b) because these valuable lands were divided into small lots with a high density of corners. Lot edges were often on river margins, so species that tolerate wet soils, (e.g. hemlock, elm, ash, basswood) may be overrepresented as low-elevation witness trees. Low-elevation areas are also the most likely to have been influenced by native peoples, post-settlement land clearing, and modern development; because major road corridors in the region mostly follow river valleys, these areas are the least forested in the region today (Fig. 2a). Productive and accessible low-elevation forests may also have a more intensive cutting history than upslope areas which may have only been cutover once. These factors are important to consider when interpreting results for lowelevation forests, such as the large apparent decreases in basswood and hemlock below $200 \mathrm{~m}$. On the other hand, it is not surprising that elm is less abundant today than it was presettlement, because the introduced Dutch elm disease decimated populations of American elm throughout its range in the early $20^{\text {th }}$ century.

\section{Conclusions}

Examining the witness tree data in the context of modern and historic forest composition data shows that the presettlement forest composition was different from the modern forest in several important ways. Until at least 1900 , red spruce was dominant at elevations $(400-700 \mathrm{~m}$ ) where it is not abundant today (Fig. 4). That primary forest fragments at these elevations now largely lack spruce suggests that not only cutting and clearing but also changing climate and acid deposition have contributed to this major change. Beech has also declined regionally as a canopy tree across most elevations, while maples and birches (especially white birch, an early successional species) are apparently far more abundant than they were prior to settlement. Oak and pine have apparently increased somewhat at low elevations, though the extent to which climate is responsible is unclear, as forests at these elevations have a long history of heavy disturbance and a potential pre-settlement sampling bias. As forests continue to change in response to climate, pollution, and management, a well-understood historical baseline will be important to understanding the long-term trajectories of these ecosystems (Clawson 1979).

\section{Acknowledgements}

We thank the librarians and archivists at the many institutions housing the historic records we used, especially B.N. Burford and D.R. Gourley at the New Hampshire Division of Records Management and Archives. This work was funded by a Mellon Challenge grant to S.P.H., and NSF's Long-term Ecological Research (LTER) program. This paper is a contribution to the Hubbard Brook Ecosystem Study, www.hubbardbrook.org.

\section{References}

Abrams, M.D. 1998. The red maple paradox. BioScience 48: 355-364.

Bailey, A.S., Hornbeck, J.W., Campbell, J.L., and Eagar, C. 2003. Hydrometerological database for Hubbard Brook Experimental Forest: 1955-2000. USDA Forest Service, NE Research Station General Technical Report NE-305.

Beckage, B., Osborne, B., Gavin, D.G., Pucko, C., Siccama, T., and Perkins, T. 2008. A rapid upward shift of a forest ecotone during 40 years of warming in the Green Mountains of Vermont. Proc. Nat. Acad. Sci. USA 105: 4197-202. doi:10.1073/pnas.0708921105

Bellemare, J., Motzkin, G., and Foster, D.R. 2002. Legacies of the agricultural past in the forested present: an assessment of historical land-use effects on rich mesic forests. J. Biogeogr. 29: 14011420. doi:10.1046/j.1365-2699.2002.00762.x

Bormann, F.H., Siccama, T.G., Likens, G.E., and Whittaker, R.H. 1970. The Hubbard Brook Ecosystem Study: Composition and dynamics of the tree stratum. Ecol. Monogr. 40: 373-388. doi:10.2307/1942336 
Carbonneau, L. 1986. Old-growth forest stands in New Hampshire: A preliminary investigation. M.S. Thesis, University of New Hampshire, Durham, NH.

Chittenden, A.K. 1904. Forest Conditions of Northern New Hampshire. State of New Hampshire Biennial Report of the Forestry Commission for 1903-1904.

Clawson, M. 1979. Forests in the long sweep of American history. Science 204:1168-1174. doi:10.1126/science.204.4398.1168

Cogbill, C.V., Burk, J., and Motzkin, G. 2002. The forests of presettlement New England, USA: spatial and compositional patterns based on town proprietor surveys. J. Biogeogr. 29:1279-1304. doi:10.1046/j.1365-2699.2002.00757.x

Cogbill, C.V., and White, P.S. 1991. The latitudeelevation relationship for spruce-fir forest and treeline along the Appalachian mountain chain. Vegetatio 94: 153-175. doi:10.1007/BF00032629

Davis, A.J., Jenkinson, L.S., Lawton, J.H., Shorrocks, B., and Wood, S. 1998. Making mistakes when predicting shifts in species range in response to global warming. Nature 391: 783-786. doi:10.1038/35842

Davis, M.B. 1989. Lags in vegetation response to greenhouse warming. Clim. Change 15: 75-82. doi:10.1007/BF00138846

Day, G.M. 1953. The Indian as an ecological factor in the northeastern forest. Ecology 34:329-346. doi:10.2307/1930900

Driscoll, C.T., Whitall, D., Aber, J.D., Boyer, E.W., Castro, M., Cronan, C., Goodale, C.L., et al. 2003. Nitrogen pollution in the northeastern United States: sources, effects, and management options. BioScience 53: 357. doi:10.1641/00063568(2003)053[0357:NPITNU]2.0.CO;2

Eager, C., and Adams, M.B. (eds). 1992. Ecology and decline of red spruce in the eastern United States. Ecological Studies 96. Springer-Verlag, New York.

Foster, D.R. 1992. Land-use history (1730-1990) and vegetation dynamics in central New England, USA. J. Ecol. 80:753-771. doi:10.2307/2260864

Goodale, C.L. 1997. Fire in the White Mountains: A historical perspective. Appalachia: 60-75.

Hamburg, S.P. 1984. Organic matter and nitrogen accumulation during 70 years of old-field succession in central New Hampshire. Ph.D. Dissertation, Yale University, New Haven, CT.
Hamburg, S.P., and Cogbill, C.V. 1988. Historical decline of red spruce populations and climatic warming. Nature 331:428-431. doi:10.1038/331428a0

Hawley, G.J., Schaberg, P.G., Eagar, C., and Borer, C.H. 2006. Calcium addition at the Hubbard Brook Experimental Forest reduced winter injury to red spruce in a high-injury year. Can. J. For. Res. 36:2544-2549. doi:10.1139/X06-221

Houston, D.R. 1994. Major new tree disease epidemics: Beech bark disease. Ann. Rev. Phytopath. 32:75-87. doi:10.1146/annurev.py.32.090194.000451

Iverson, L.R., and Prasad, A.M. 2002. Potential tree species shifts with five climate change scenarios in the Eastern United States. For. Ecol. Manage. 155:205-222. doi:10.1016/S0378-1127(01)00559-X

Johnson, A.H. 1992. The role of abiotic stresses in the decline of red spruce in high elevation forests of the eastern United States. Ann. Rev. Phytopath. 30:349-367. doi:

10.1146/annurev.py.30.090192.002025

Kelly, A.E., and Goulden, M.L. 2008. Rapid shifts in plant distribution with recent climate change. Proc. Nat. Acad. Sci. 105: 11823-6. doi:10.1073/pnas.0802891105.

Leak, W.B., and Smith, M.L. 1996. Sixty years of management and natural disturbance in a New England forested landscape. For. Ecol. Manage. 81:63-73. doi:10.1016/0378-1127(95)03662-8

Lenoir, J., Gégout, J.C., Marquet, P.A., de Ruffray, P., and Brisse, $H$. 2008. A significant upward shift in plant species optimum elevation during the 20th century. Science 320: 1768-71. doi:10.1126/science.1156831

Lorimer, C.G. 1977. The presettlement forest and natural disturbance cycle of northeastern Maine. Ecology 58:139-148. doi:10.2307/1935115

Manies, K.L., and Mladenoff, D.J. 2000. Testing methods to produce landscape-scale presettlement vegetation maps from the U.S. public land survey records. Landscape Ecology 15:741-754. doi: 10.1023/A:1008115200471.

Martin, C.W. 1977. Distribution of tree species in an undisturbed northern hardwood-spruce-fir forest, The Bowl, New Hampshire. USDA Forest Service, NE Experiment Station Research Note NE-244. 
Martin, C.W., and A.S. Bailey. 1999. Twenty years of change in a northern hardwood forest. For. Ecol. Manage. 123:253-260. doi:10.1016/S03781127(99)00045-6

Meuller-Dombois, D., and Ellenberg, H. 1974. Aims and methods in vegetation ecology. John Wiley and Sons, New York.

Rhoads, A.G. 2005. The effects of natural and anthropogenic disturbance on the composition and structure of the northern hardwood forest. Ph.D. Dissertation, Brown University, Providence, RI.

Richardson, A.D., Lee, X., and Friedland, A.J. 2004. Microclimatology of treeline spruce-fir forest in mountains of the northeastern United States. Agric. For. Meteorol. 125:53-66. doi: 10.1016/j.agrformet.2004.03.006

Robinson, G.R. 2003. Generalized lithology and lithogeochemical character of near-surface bedrock in the New England region. Reston, VA. USGS Open-File Report 03-225. http://pubs.usgs.gov/of/2003/of03-225/

Russell, H.S. 1980. Indian New England before the Mayflower. University Press of New England, Hanover, $\mathrm{NH}$.
Sargent, C.S. 1884. Report on the Forests of North America. U.S. Census Office.

Satterson, K.A. 1977. A vegetation history of Williamstown. Honors thesis, Williams College, Williamstown, MA.

Schwartz, P.A., Fahey, T.J., and McCulloch, C.E. 2003. Factors controlling spatial variation of tree species abundance in a forested landscape. Ecology 84:1862-1878.

Shuman, B., Newby, P., Huang, Y., and Webb, T. III. 2004. Evidence for the close climatic control of New England vegetation history. Ecology 85:12971310.

Siccama, T.G. 1971. Presettlement and present forest vegetation in northern Vermont with special reference to Chittenden County. Am. Midl. Nat. 85:153-172.

Torbert, E.N. 1935. The evolution of land utilization in Lebanon, New Hampshire. Geogr. Rev. 25:209230. doi:10.2307/209597

Westveld, M. 1953. Ecology and silviculture of the spruce-fir forests of eastern North America. J. Forest 51:422-430. 
Table 1. Towns represented in the witness tree data set, along with the elevation range of usable tree data and the number of trees in each genus.

\begin{tabular}{|c|c|c|c|c|c|c|c|c|c|c|c|}
\hline \multirow{3}{*}{$\begin{array}{l}\text { Town } \\
\text { Bartlett }\end{array}$} & \multicolumn{11}{|c|}{ Elevaton $(\mathrm{m})$} \\
\hline & \multicolumn{2}{|c|}{ Min / Max } & Beech & Birch & Fir & Hemlock & Maple & Pine & Spruce & Other & TOTAL \\
\hline & 183 & 508 & & 1 & & 5 & 1 & & & & 7 \\
\hline Benton & 323 & 1225 & 38 & 33 & 4 & 7 & 10 & & 29 & 8 & 129 \\
\hline Bethlehem & 384 & 1170 & 8 & 15 & 8 & 1 & 4 & & 32 & & 68 \\
\hline Campton & 150 & 710 & 150 & 21 & 2 & 99 & 49 & 23 & 74 & 39 & 457 \\
\hline Crawford's Purchase & 492 & 879 & & 16 & 4 & & 1 & & 10 & & 31 \\
\hline Dorchester & 342 & 821 & 52 & 24 & 9 & 13 & 14 & & 49 & 1 & 162 \\
\hline Easton & 349 & 431 & & & & 2 & & & & & 2 \\
\hline Elkin and Sargent's Grant & 384 & 920 & 3 & 2 & 2 & 1 & 1 & 1 & 2 & & 12 \\
\hline Franconia & 515 & 1426 & 3 & 12 & 1 & & & & 17 & & 33 \\
\hline Gorham & 500 & 686 & & 2 & & & & & 2 & 1 & 5 \\
\hline Hanover & 115 & 683 & 159 & 24 & 1 & 99 & 60 & 9 & 23 & 53 & 428 \\
\hline Hart's Location & 646 & 1134 & 1 & & & & & & & & 1 \\
\hline Haverhill & 137 & 472 & 2 & 4 & & 4 & 1 & 3 & & 2 & 16 \\
\hline Jackson & 490 & 586 & 3 & 1 & 1 & & & & & & 5 \\
\hline Lebanon & 97 & 484 & 154 & 30 & & 131 & 60 & 77 & 1 & 83 & 536 \\
\hline Lincoln & 288 & 1274 & 6 & 12 & 13 & 3 & 2 & 1 & 18 & & 55 \\
\hline Low \& Burbank's Grant & 472 & 892 & & & & & 1 & & 3 & & 4 \\
\hline Martin's Location & 421 & 811 & 1 & 3 & & 1 & & & 1 & 1 & 7 \\
\hline Nash \& Sawyer's Location & 524 & 660 & 2 & 4 & 1 & & & & 1 & & 8 \\
\hline Orford & 225 & 594 & 42 & 12 & & 26 & 16 & & 26 & 19 & 141 \\
\hline Rumney & 207 & 792 & 41 & 13 & 5 & 18 & 6 & 2 & 41 & 4 & 130 \\
\hline Shelburne & 378 & 378 & & & & & 1 & & & & 1 \\
\hline Thornton & 170 & 938 & 11 & 14 & & 2 & 4 & & 14 & & 45 \\
\hline Warren & 521 & 803 & 3 & 6 & 6 & 1 & 1 & & 1 & & 18 \\
\hline Waterville & 416 & 596 & 2 & & 1 & & & & & & 3 \\
\hline Woodstock & 189 & 1181 & 52 & 31 & 19 & 17 & 13 & & 93 & & 225 \\
\hline TOTAL & 97 & 1426 & 733 & 280 & 77 & 430 & 245 & 116 & 437 & 211 & 2529 \\
\hline
\end{tabular}

Note: Trees located on town boundaries were assigned to the town for which the map was drawn. 
Table 2. The primary historical data for central New Hampshire identified trees to genus, thus all analyses were conducted at the genus level. Most genera include only one or two species native to the study region. $n$ refers to the number of individual trees in the compiled historic data.

Genus reported Likely species n

Genera representing at least $10 \%$ of any $100 \mathrm{~m}$ elevation class

$\begin{array}{ll}\text { Beech } & \text { Fagus grandifolia Ehrh. } \\ \text { Spruce } & \text { Picea rubens Sarg. } \\ \text { Hemlock } & \text { Tsuga canadensis L. } \\ \text { Birch } & \text { Betula alleghaniensis Britton and B. papyrifera Marsh. } \\ \text { Maple } & \text { Acer saccharum L. and A. rubrum L. At least one A. pensylvanicum L. } \\ \text { Pine } & \text { Pinus strobus L., possibly some P.resinosa Ait. and P. rigida Mill. } \\ \text { Fir } & \text { Abies balsamea L. }\end{array}$

Genera representing at least $0.1 \%$ of all sample data

$\begin{array}{ll}\text { Ash } & \text { Fraxinus americana L. and F. nigra Marsh. } \\ \text { Basswood } & \text { Tilia americana L. } \\ \text { Oak } & \text { Quercus spp. (primarily Q. rubra L. with some Q. alba L.) } \\ \text { Elm } & \text { Ulmus americana L. } \\ \text { Butternut } & \text { Juglans cinerea } \text { L. } \\ \text { Hornbeam } & \text { Ostrya virginiana (Mill.) K. Koch and Carpinus caroliniana Walter } \\ \text { Aspen } & \text { Populus tremuloides Michx. and } P \text {. grandidentata Michx. }\end{array}$


Table 3. Pairwise similarity coefficients among the presettlement forest composition from $580-700 \mathrm{~m}$ elevation, and each of the historic direct, modern primary, and modern secondary forests for which we have comparable composition data (Fig. 5).

\begin{tabular}{|c|c|c|c|c|c|c|c|c|c|c|c|c|c|c|c|c|}
\hline & $\begin{array}{l}\text { o } \\
\dot{0} \\
\stackrel{0}{N} \\
\frac{\pi}{4}\end{array}$ & 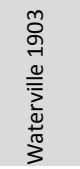 & $\begin{array}{l}\infty \\
0 \\
\infty \\
\infty \\
ِ\end{array}$ & 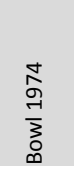 & $\begin{array}{l}\frac{7}{\sigma} \\
\frac{7}{3} \\
0 \\
0\end{array}$ & 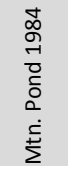 & 离 & 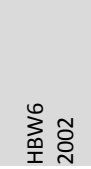 & 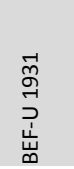 & 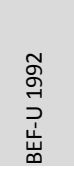 & $\begin{array}{l}\vec{m} \\
\stackrel{-}{न} \\
\sum_{\substack{1 \\
\oplus}}\end{array}$ & 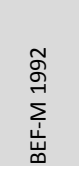 & 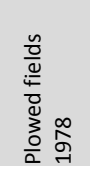 & 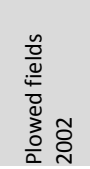 & 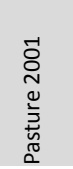 & 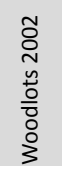 \\
\hline $\begin{array}{l}\text { Presettlement } \\
\text { (this study) } \\
580-700 \text { m elev. }\end{array}$ & 0.68 & 0.85 & 0.87 & 0.62 & 0.59 & 0.41 & 0.56 & 0.46 & 0.77 & 0.79 & 0.49 & 0.48 & 0.27 & 0.22 & 0.57 & 0.54 \\
\hline FIA 2004-9 & & 0.62 & 0.61 & 0.63 & 0.64 & 0.56 & 0.76 & 0.66 & 0.85 & 0.62 & 0.64 & 0.54 & 0.46 & 0.50 & 0.53 & 0.72 \\
\hline Waterville 1903* & & & 0.83 & 0.74 & 0.71 & 0.56 & 0.53 & 0.51 & 0.75 & 0.80 & 0.64 & 0.62 & 0.23 & 0.18 & 0.50 & 0.53 \\
\hline L\&B 1903* & & & & 0.74 & 0.71 & 0.56 & 0.53 & 0.50 & 0.75 & 0.80 & 0.64 & 0.62 & 0.22 & 0.17 & 0.49 & 0.53 \\
\hline Bowl 1974† & & & & & 0.86 & 0.75 & 0.64 & 0.57 & 0.71 & 0.61 & 0.76 & 0.76 & 0.26 & 0.24 & 0.30 & 0.57 \\
\hline Bowl 1994‡ & & & & & & 0.73 & 0.74 & 0.67 & 0.78 & 0.61 & 0.81 & 0.71 & 0.32 & 0.31 & 0.33 & 0.67 \\
\hline Mtn. Pond 1984§ & & & & & & & 0.74 & 0.67 & 0.74 & 0.58 & 0.79 & 0.67 & 0.29 & 0.28 & 0.29 & 0.65 \\
\hline HBW6 1965|| & & & & & & & & 0.89 & 0.77 & 0.53 & 0.69 & 0.51 & 0.31 & 0.53 & 0.30 & 0.72 \\
\hline HBW6 2002ף & & & & & & & & & 0.69 & 0.57 & 0.72 & 0.55 & 0.31 & 0.56 & 0.30 & 0.74 \\
\hline BEF-U 1931\# & & & & & & & & & & 0.76 & 0.72 & 0.63 & 0.43 & 0.40 & 0.52 & 0.73 \\
\hline BEF-U 1992\# & & & & & & & & & & & 0.61 & 0.63 & 0.34 & 0.29 & 0.66 & 0.62 \\
\hline BEF-M 1931\# & & & & & & & & & & & & 0.78 & 0.34 & 0.36 & 0.35 & 0.77 \\
\hline BEF-M 1992\# & & & & & & & & & & & & & 0.36 & 0.32 & 0.42 & 0.67 \\
\hline Plowed fields $1978^{* *}$ & & & & & & & & & & & & & & 0.66 & 0.67 & 0.40 \\
\hline Plowed fields $2002+\dagger$ & & & & & & & & & & & & & & & 0.50 & 0.46 \\
\hline Pasture 2001‡‡ & & & & & & & & & & & & & & & & 0.40 \\
\hline Woodlots 2002 $\ddagger \ddagger$ & & & & & & & & & & & & & & & & \\
\hline
\end{tabular}


Figure 1. a) Our study area includes 26 towns in central New Hampshire, USA. The number of witness trees mapped and identified to genus in each town is indicated. In italics is the percentage of each town reported as agriculturally "improved" (i.e. cleared) in the 1860 agricultural census. Locations of "case-study" plots where $20^{\text {th }}$ century forest composition data were collected are shown. b) Elevation within our study area.

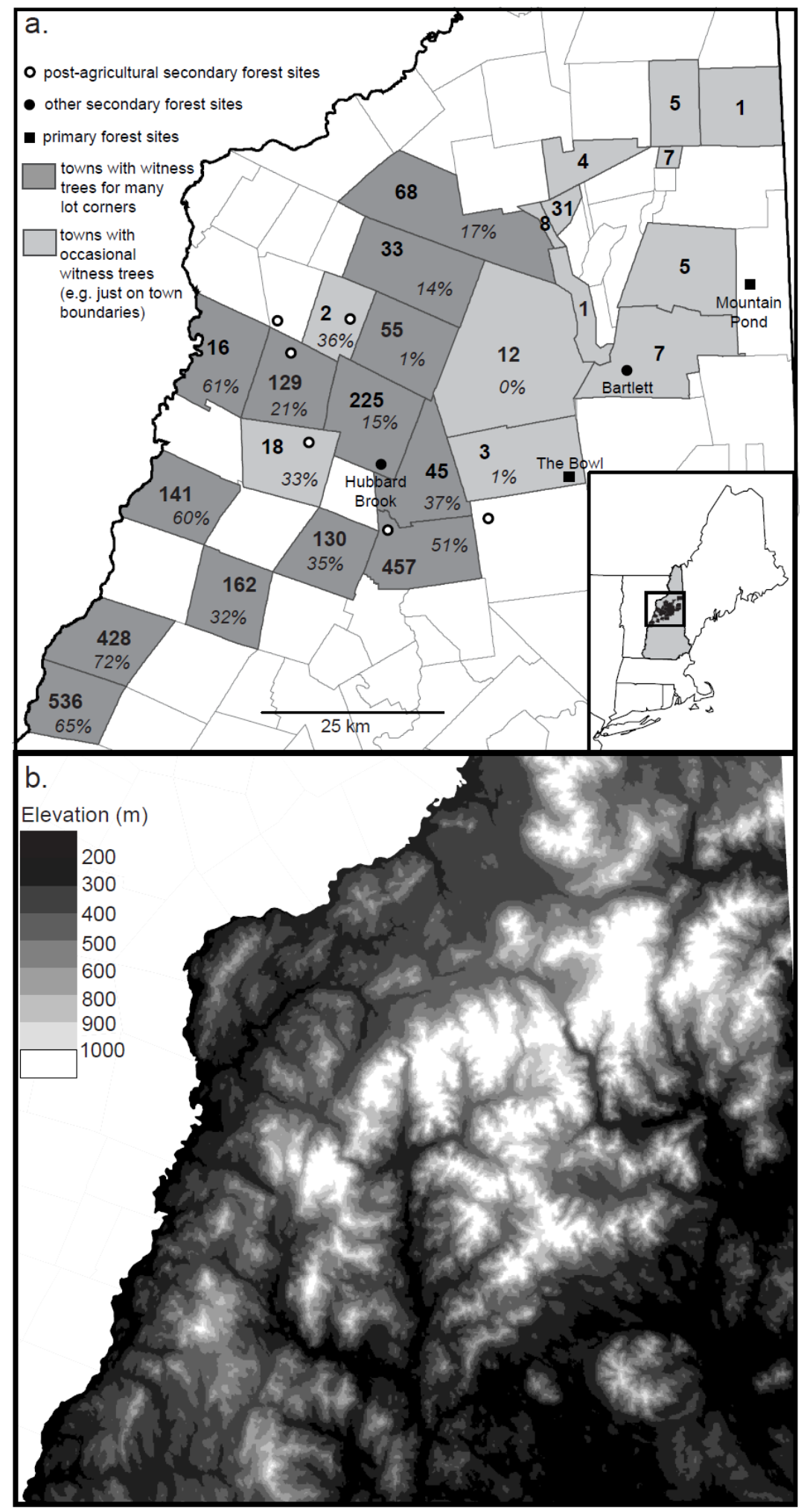


Figure 2. a) Forest cover in each elevation class in the 17 Grafton County towns in our study area near the peak of agriculture (1860) and in 2001. Land-cover data for 2001 are from GRANIT. Data for 1860 were calculated by matching farmer names from the 1860 Agricultural Census schedules to the home locations (Walling 1860). Water accounts for $<5 \%$ of land cover at all elevations. We assumed all land not cleared for agriculture was forest. Almost all forest land in the study area has been cutover at least once since European settlement. Note that the $1000+\mathrm{m}$ data does not consider areas above treeline (typically over $1200 \mathrm{~m}$ ). b) The elevation distribution of the presettlement and FIA data sets, compared to the expected distribution if sampling was spatially random across the study area.
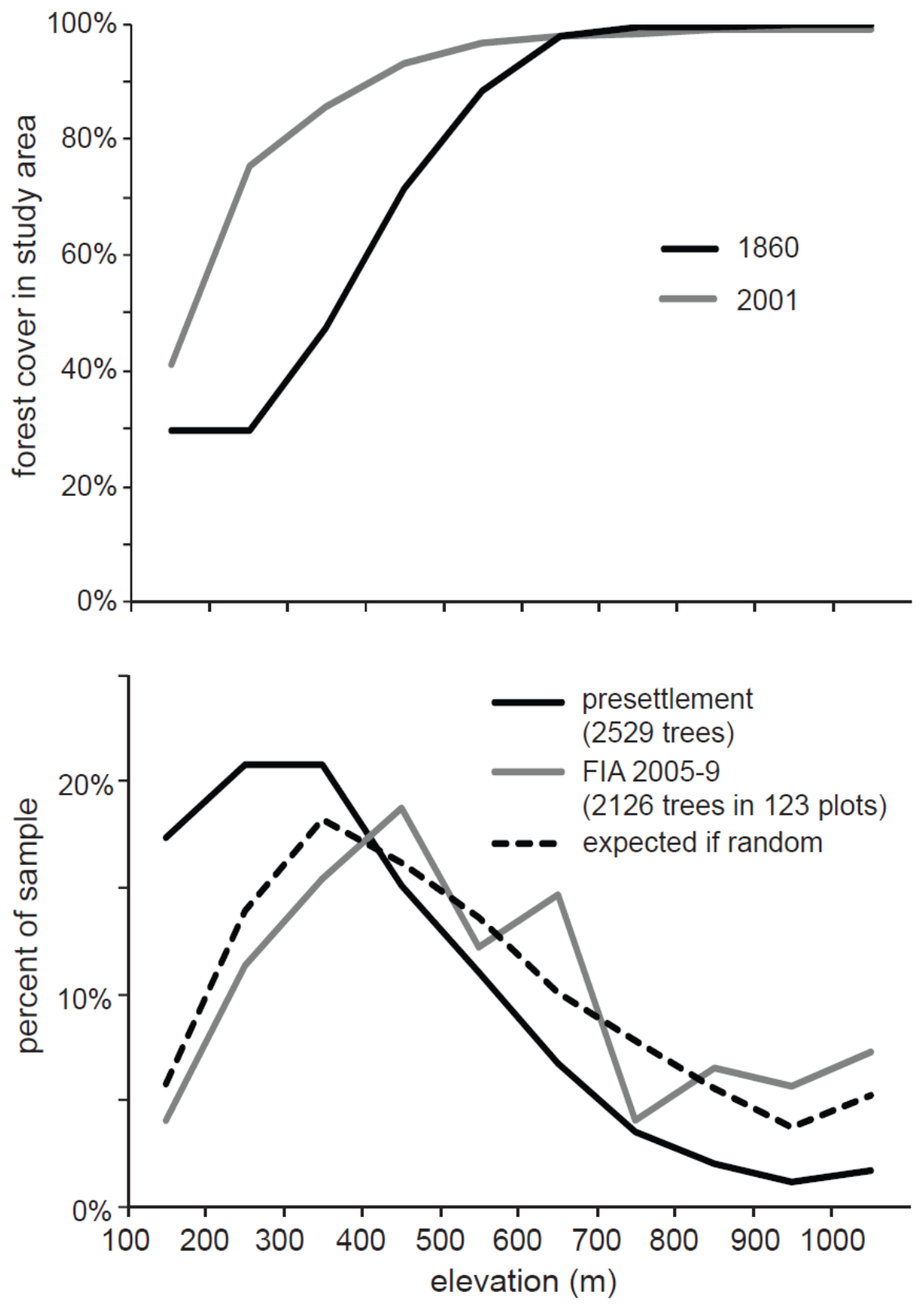
Figure 3. Presettlement (witness trees) and modern (USFS FIA program) distribution of each genus with elevation for the 26 towns studied in central New Hampshire. Significance for differences between the two data sets in an elevation category are indicated as follows: ${ }^{*}=p<0.05 ;{ }^{*}=p<0.01 ; * * *=p<0.001$.
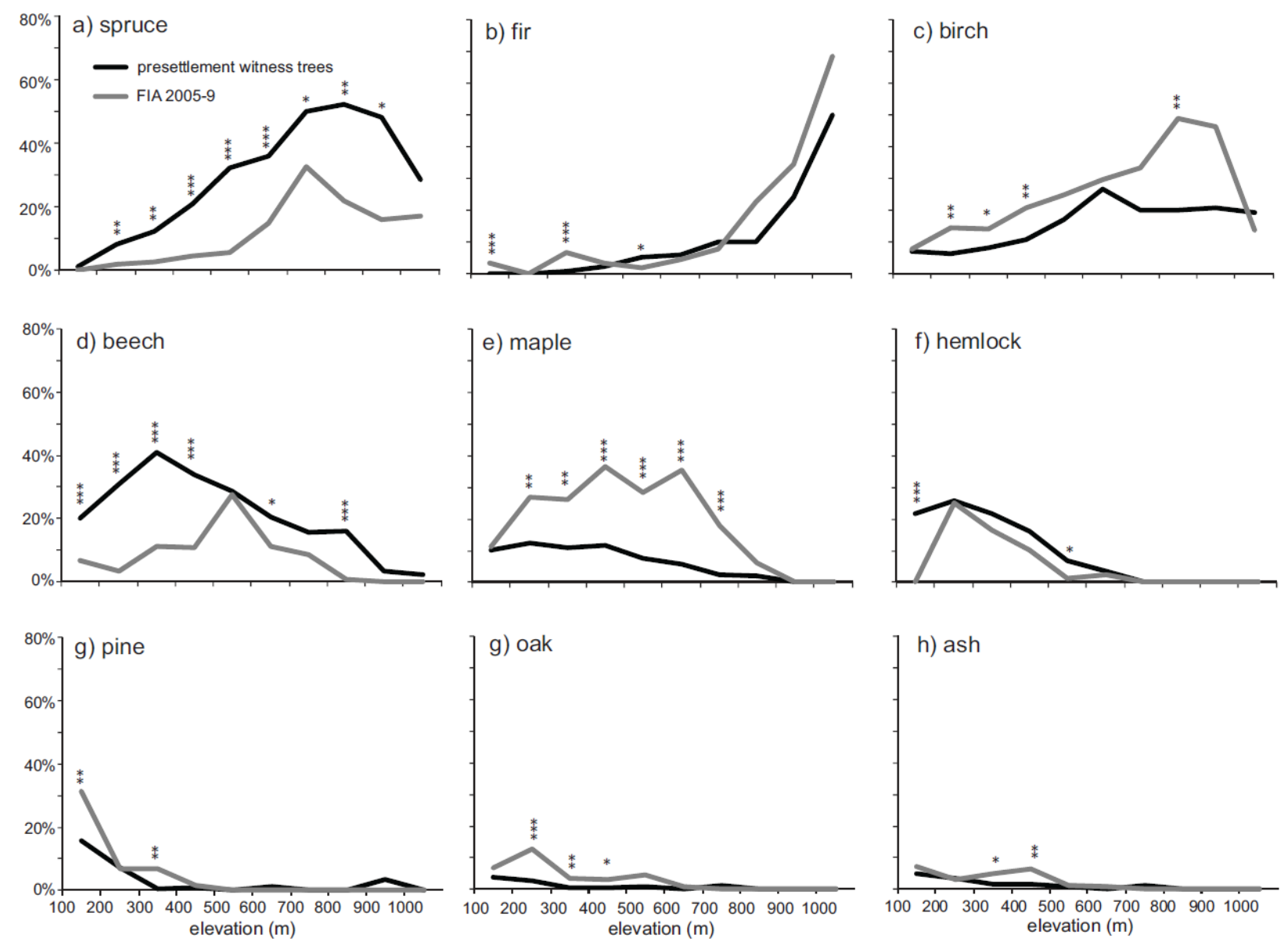
Figure 4. a) Number of genera reported in the presettlement and FIA datasets, across elevation classes. b) Shannon's diversity index (based on genera).
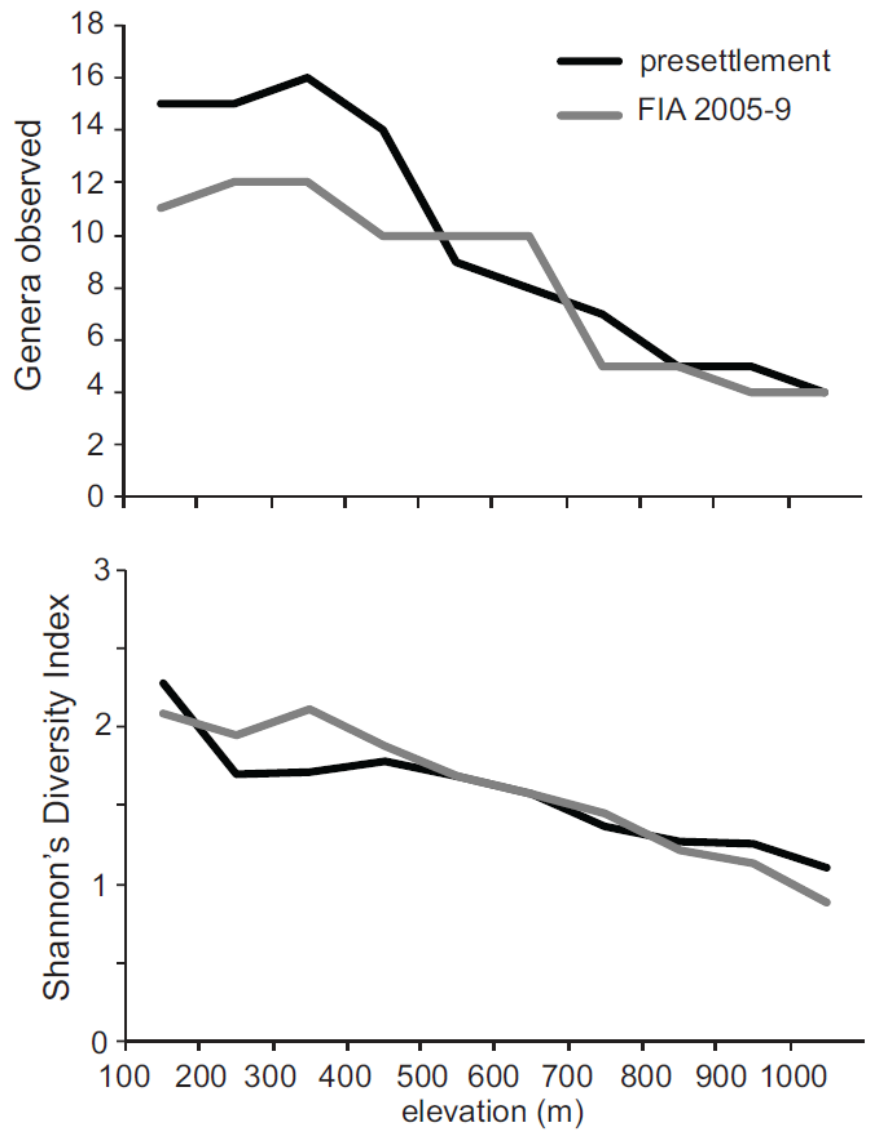
Figure 5. A comparison of presettlement (a), historic (b-c), modern primary (d-e), modern FIA ( $f$ ) and various modern secondary forests $(\mathrm{g}-\mathrm{l})$ in central New Hampshire. Genera are abbreviated as follows: $\mathrm{S}=\mathrm{spruce}, \mathrm{Bi}=$ birch, $\mathrm{Be}=$ beech, $\mathrm{M}=$ maple, $\mathrm{F}=$ fir, $\mathrm{H}=$ hemlock, and $\mathrm{O}=$ other (see Table 2 ). Where the data exist, we indicate whether birches are predominantly yellow birch (YB) or white birch (WB), and whether maples are predominantly red maple (RM) or sugar maple (SM). Where the "other" category is $>5 \%$, its major components are listed.
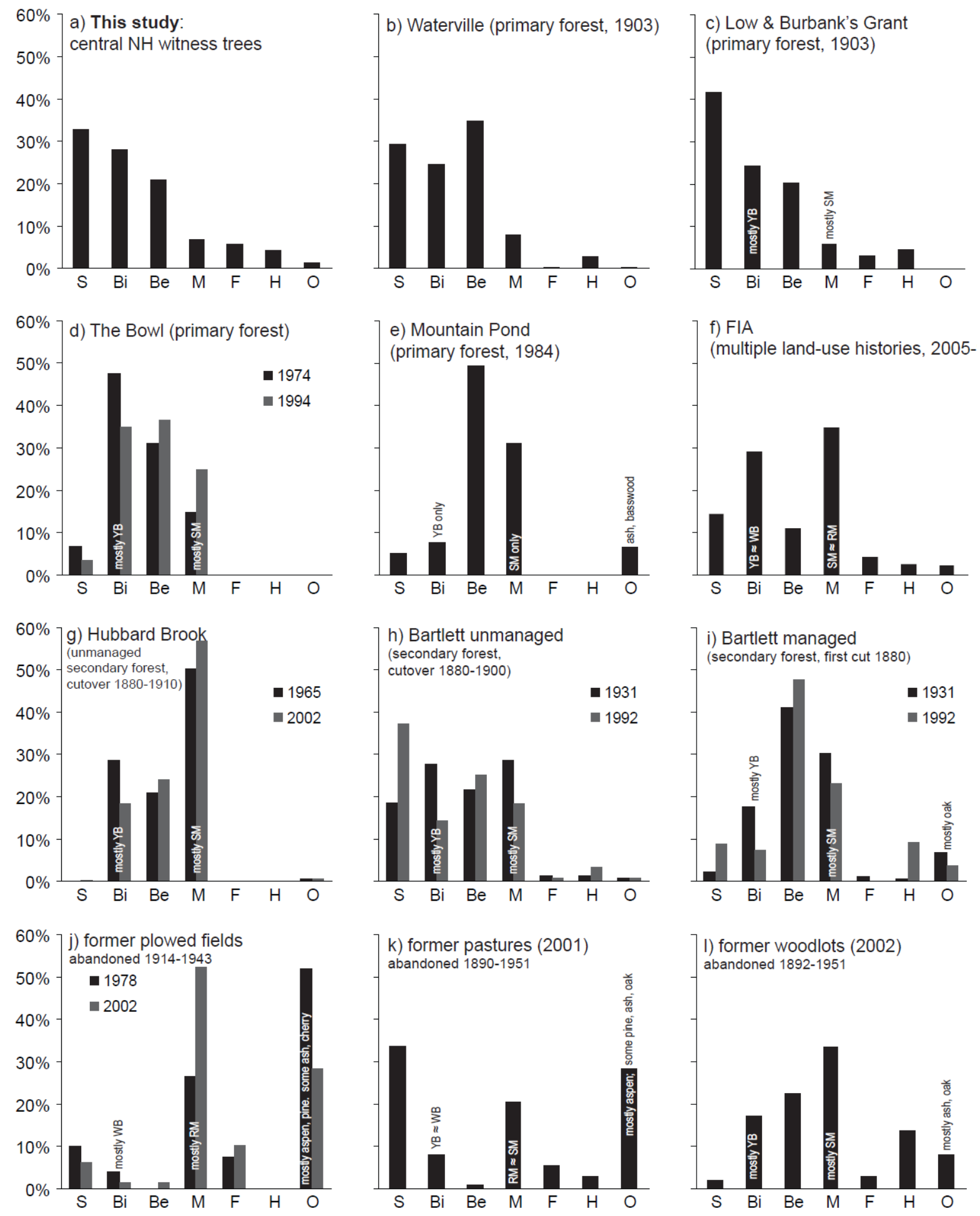
Figure 6. Percentage of canopy trees that are spruce or fir in the presettlement and modern FIA datasets. Significance is shown as in Figure 3.

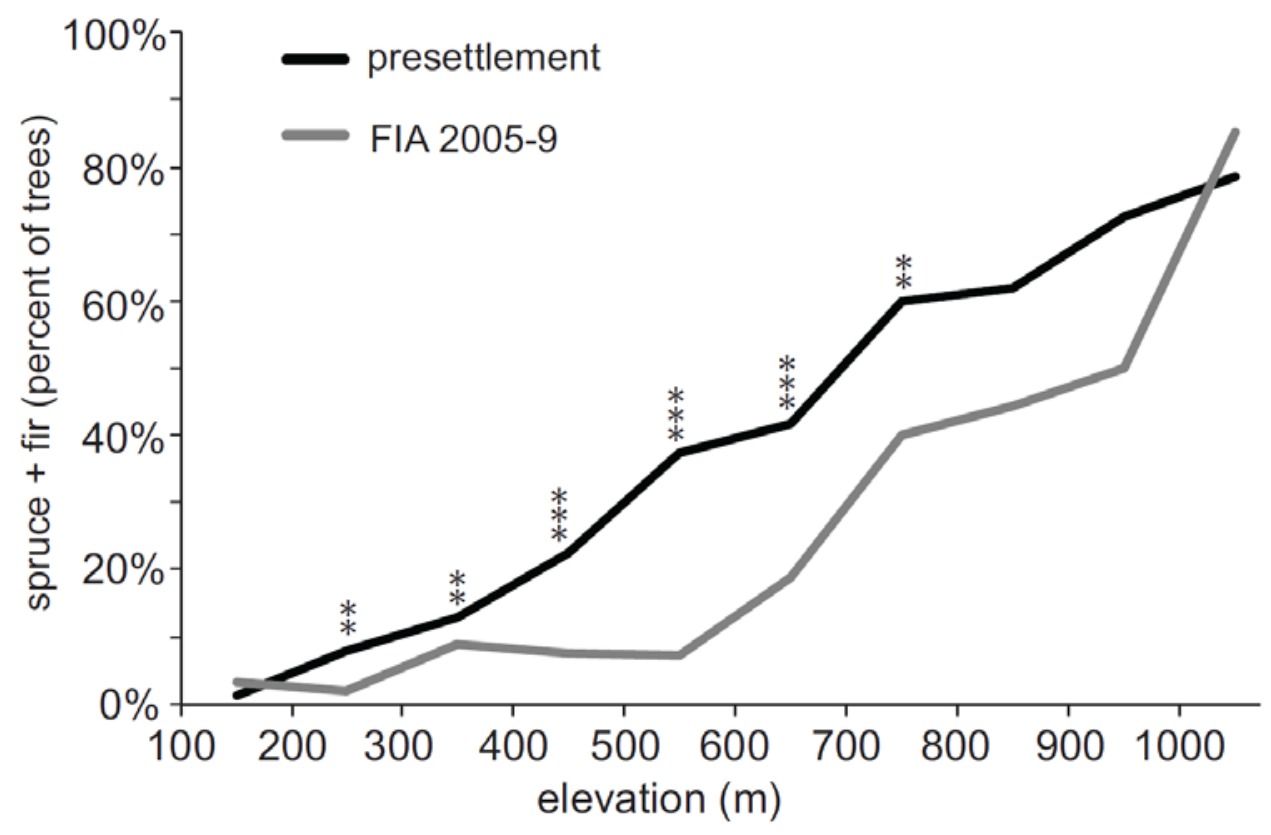

